\title{
Dynamics of Area, Production, Productivity and Trade of Sugarcane in India: Evidences from Uttar Pradesh and Maharashtra, India
}

\author{
Ajay Kumar* and Rakesh Singh \\ Department of Agricultural Economics, Institute of Agricultural Sciences, B.H.U., \\ Varanasi-221005, India \\ *Corresponding author
}

\begin{tabular}{|l|}
\hline Ke y w or d s \\
Growth, Trend, \\
Production, \\
Sugarcane, Sugar \\
\hline Article Info \\
\hline Accepted: \\
26 April 2018 \\
Available Online: \\
10 May 2018 \\
\hline \hline
\end{tabular}

A B S T R A C T

The present study is conducted with a view to analyze growth and trend in Area, Production, Productivity and trade of sugarcane producing in India. A time series data from 1970-1971 to 2014-2015 (45 year) of major sugarcane producing states Uttar Pradesh and Maharashtra in India was used. The compound growth rate as well as trend analysis indicated that the Area Production and Productivity under sugarcane in Uttar Pradesh and Maharashtra. The area, production under sugarcane in Uttar Pradesh was more than Maharashtra but productivity of sugarcane in Uttar Pradesh was less than Maharashtra. The results showed that area, production and productivity of sugarcane was increased over the time period due to more area brought under new HYV and improved the technology of showing method of sugarcane in both states. It is revealed from the results that area, production and productivity of sugarcane is increasing at the rate of 1.20 per cent, 2.27 per cent and 1.20 per cent respectively in Uttar Pradesh and 4.10 per cent, 3.80 per cent and 0.2 per cent respectively in Maharashtra. At India level area, production and productivity grew at the rate of 1.6 per cent, 2.5 per cent and 0.9 per cent respectively in India. The export and import of sugar gained at the rate of 3.04 per cent and 18.84 per cent respectively.

\section{Introduction}

Sugarcane is a major cash crop of India, particularly in UP, Maharashtra, Tamil Nadu, Karnataka, Andhra Pradesh, Bihar, Gujarat, and Foot hills of Uttarakhand and it plays a pivotal role in the national economy. However paltering yield level declining factor productivity, increasing production cost and slashing sugar prices in the market in the recent years pose a real concern to crop diversification in sugar based production. India ranks second in the world in sugarcane production after Brazil. In India during 201415 sugarcane was cultivated in an area of 51.38 lakh hectares with production of 35.04 million tonnes and with the productivity of 69.7 tonnes/ha. In Uttar Pradesh during 201415 , the area under sugarcane crop was 2228 thousand hectares and production was 138481 thousand tonnes with productivity of 621.55 Q/ha, and in Maharashtra area under sugarcane crop was 1048 thousand hectares and production was 81870 thousand tonnes with productivity of $781.22 \mathrm{Q} /$ ha during same period. During 2014-15, area, production and 
productivity were 5144 thousand hectares, 359330 thousand tones and $698.59 \mathrm{Q} / \mathrm{ha}$ respectively at country level (Anonymous, 2015).

Sugar industry is an important agro-based industry that impacts rural livelihood of about 50 million sugarcane farmers and around 5 lakh workers directly employed in sugar mills. Employment is also generated in various ancillary activities relating to transport, trade servicing of machinery and supply of agriculture inputs. Present study based on the growth rate of area, production and productivity of sugarcane in Uttar Pradesh, Maharashtra and India as a whole and growth rate in export and import of sugar in India.

\section{Materials and Methods}

\section{Data}

The study on growth rate in area, production and productivity of sugarcane in two major producing states of India viz. Uttar Pradesh and Maharashtra were selected purposively. Forty five years of time series data on area, production and productivity of sugarcane crop were taken from the period 1970-1971 to 2014-2015 from the Department of Agriculture Cooperation and Farmers Welfare. Export and import of sugar data were collected from the period 1971 to 2015 from the FAOSTAT. Further, study period was divided into three similar sub periods for the analysis of area, production and productivity of sugarcane and export and import of sugar in India. Sub periods were made for the study on area, production and productivity which were as follow:

Sub Period I (1970-71 to $194-85)$

Sub Period II (1985-86 to 1999-2000)

Sub Period III (2000-01 to 2014-15)

For the export and import of sugar,
Sub Period I (1971 to 1985)

Sub Period II (1986 to 2000)

Sub Period III (2001 to 2015)

\section{Analytical tool}

Compound growth rates in area, production and productivity sugarcane and export and import of sugar in India were estimated by using the exponential growth function of the form:

$Y_{t}=a b^{t}$

Where,

$Y_{t}=$ dependent variable for which growth rate is estimated

$\mathrm{a}=$ intercept

$\mathrm{b}=$ regression coefficient

$\mathrm{t}=$ time variable

The growth rate coefficient (b's) was computed by transforming the equation in log form

$\log Y_{t}=\log a+t \log b$

The values of ' $a$ ' and ' $b$ ' were estimated by using ordinary least squares estimation technique. Thus, compound growth rate $(\mathrm{g})$ in per cent was computed as

$\mathrm{g}=$ Antilog $[(\log \mathrm{b}-1) * 100]$

\section{Results and Discussion}

The compound growth rates of area, production and productivity of Sugarcane crops in Uttar Pradesh State for the sub period I (1970-71 to 1984-85), sub Period II - 198586 to $1999-2000$, sub Period III (2000-01 to 2014-15) and overall Period (1970-71 to 20142015) were worked out and depicted in Table 1. 
The results of CGR model for area, production and productivity of sugarcane crop during 1970-71 to 2014-1 is presented in Table 1 indicates that the area, production and productivity under of sugarcane crop registered a significant and positive growth rate as a whole period 1970-71to 2014-15 in Uttar Pradesh. The highest growth rate in sugarcane area was observed in sub period II (2.0\%) and lowest growth rate in sub period III $(0.7 \%)$. Sugarcane production was observed a significant and highest growth rate in the sub period II (4.3\%) and lowest in sub period III $(0.5 \%)$. Sugarcane productivity with highest growth rate got significant and positive in sub period II (2.3\%) and lowest in sub period III $(0.5 \%)$. The results are agreement with the findings by Saraswati et al., (2012).

It is evident from Table 2 that the area, production under of sugarcane crop registered a significant and positive growth rate and productivity is observed in negative growth rate and insignificant period 1970-71 to 20142015 in Maharashtra. In Maharashtra state, the area sugarcane recorded positive and significant growth while, area under other state. Sugarcane area registered is positive and significant and highest growth rate in observed in III period $(6.0 \%)$ and lowest growth rate in I period (4.5\%). In case of sugarcane production III period (7.0\%) observed in positive and significant growth rate and lowest II period $(4.8 \%)$ sugarcane productivity observed in highest growth rate in I period $(2.1 \%)$, lowest and negative in II period ($0.1 \%$ ). These findings are in agreement with the results obtained by Acharya et al., (2012) and Samui et al., (2005).

Growth rate area, production and productivity of sugarcane crop during 1970-71 to 2014-15 is presented in Table 3 indicates that the area, production and productivity under sugarcane observed in significant and positive growth rate as a whole, during the period. Sugarcane area registered in highest growth rate in (2.4\%) sub period II and lowest growth rate in $(1.5 \%)$ sub period III, sugarcane production observed in highest growth rate in $(3.8 \%)$ sub period II and lowest growth rate in (2.1\%) sub period III. Sugarcane productivity highest growth rate get significant and positive in sub period I $(1.5 \%)$, lowest in sub period III $(0.4 \%)$.

Table.1 Growth rates in area, production and productivity of sugarcane of Uttar Pradesh

\begin{tabular}{|c|c|c|c|c|c|}
\hline Items & Particulars & $\begin{array}{c}\text { Sub Period I } \\
(1970-71 \text { to } 1984- \\
85)\end{array}$ & $\begin{array}{c}\text { Sub Period II } \\
\text { (1985-86 to 1999- } \\
\text { 2000) }\end{array}$ & $\begin{array}{l}\text { Sub Period III } \\
(2000-01 \text { to } \\
2014-2015)\end{array}$ & $\begin{array}{c}\text { Study Period } \\
(1970-71 \text { to } \\
2014-2015)\end{array}$ \\
\hline Area & $\begin{array}{l}\text { Standard Error } \\
\text { F. Value } \\
\mathrm{R}^{2} \\
\text { Growth rate }\end{array}$ & $\begin{array}{c}2.9899 \\
11.870 \\
0.477 \\
1.6^{* * *}\end{array}$ & $\begin{array}{c}2.1544 \\
30.422 \\
0.701 \\
2.0 * * *\end{array}$ & $\begin{array}{l}3.7697 \\
7.877 \\
0.377 \\
0.7 * *\end{array}$ & $\begin{array}{c}0.0620 \\
279.133 \\
0.867 \\
1.2 * * *\end{array}$ \\
\hline Production & $\begin{array}{l}\text { Standard Error } \\
\text { F. Value } \\
\mathrm{R}^{2} \\
\text { Growth rate }\end{array}$ & $\begin{array}{c}2.9335 \\
14.55 \\
0.528 \\
2.6^{* * *}\end{array}$ & $\begin{array}{c}2.1544 \\
55.73 \\
0.811 \\
4.3 * * *\end{array}$ & $\begin{array}{c}3.7697 \\
10.99 \\
0.458 \\
1.2 * * *\end{array}$ & $\begin{array}{c}0.1182 \\
263.577 \\
0.860 \\
2.2 * * *\end{array}$ \\
\hline Productivity & $\begin{array}{l}\text { Standard Error } \\
\text { F. Value } \\
\mathrm{R}^{2} \\
\text { Growth rate }\end{array}$ & $\begin{array}{c}3.7275 \\
5.97 \\
0.291 \\
1.0 * *\end{array}$ & $\begin{array}{l}1.1980 \\
35.33 \\
0.730 \\
2.3 * * *\end{array}$ & $\begin{array}{c}4.5689 \\
4.39 \\
0.253 \\
0.5^{*}\end{array}$ & $\begin{array}{c}0.0806 \\
279.133 \\
0.867 \\
1.0 * * *\end{array}$ \\
\hline
\end{tabular}

$* * *, * *, *$ indicates at $1 \%, 5 \%$ and $10 \%$ level of significance respectively

Note: Calculated by author from the data obtained from Department of Agricultural Cooperation \& Farmers Welfare, Government of India. 
Table.2 Growth rates in area, production and productivity of sugarcane of Maharashtra

\begin{tabular}{|c|c|c|c|c|c|}
\hline Items & Particulars & $\begin{array}{c}\text { Sub Period I } \\
\text { (1970-71 to } \\
1984-85)\end{array}$ & $\begin{array}{c}\text { Sub Period } \\
\text { II }(1985-86 \\
\text { to } 1999- \\
2000)\end{array}$ & $\begin{array}{l}\text { Sub Period } \\
\text { III }(2000-01 \\
\text { to 2014- } \\
2015)\end{array}$ & $\begin{array}{c}\text { Study Period } \\
(1970-71 \text { to } \\
2014-2015)\end{array}$ \\
\hline Area & $\begin{array}{l}\text { Standard Error } \\
\mathrm{F} \text {. Value } \\
\mathrm{R}^{2} \\
\text { Growth rate }\end{array}$ & $\begin{array}{c}2.2237 \\
41.282 \\
0.761 \\
4.5^{* * *}\end{array}$ & $\begin{array}{c}2.2728 \\
48.654 \\
0.789 \\
5.5 * * *\end{array}$ & $\begin{array}{c}3.3562 \\
12.726 \\
0.495 \\
6.0 * * *\end{array}$ & $\begin{array}{c}6.2140 \\
332.297 \\
0.885 \\
4.1 * * *\end{array}$ \\
\hline Production & $\begin{array}{l}\text { Standard Error } \\
\mathrm{F} \text {. Value } \\
\mathrm{R}^{2} \\
\text { Growth rate }\end{array}$ & $\begin{array}{c}1.6945 \\
48.654 \\
0.789 \\
6.7 * * *\end{array}$ & $\begin{array}{c}2.6110 \\
41.282 \\
0.761 \\
4.8 * * *\end{array}$ & $\begin{array}{c}3.6184 \\
10.493 \\
0.447 \\
7.0 * *\end{array}$ & $\begin{array}{c}6.9262 \\
171.568 \\
0.800 \\
3.8 * * *\end{array}$ \\
\hline Productivity & $\begin{array}{l}\text { Standard Error } \\
\text { F. Value } \\
\mathrm{R}^{2} \\
\text { Growth rate }\end{array}$ & $\begin{array}{c}2.6846 \\
15.344 \\
0.541 \\
2.1 * * *\end{array}$ & $\begin{array}{c}3.3959 \\
7.38 \\
0.004 \\
-0.1\end{array}$ & $\begin{array}{c}4.6360 \\
0.05 \\
0.00 \\
0.9 *\end{array}$ & $\begin{array}{c}12.0737 \\
3.861 \\
0.082 \\
-0.2\end{array}$ \\
\hline
\end{tabular}

$* * *, * *, *$ indicates at $1 \%, 5 \%$ and $10 \%$ level of significance respectively

Note: Calculated by author from the data obtained from Department of Agricultural Cooperation \& Farmers Welfare, Government of India.

Table.3 Growth rates in area, production and productivity of sugarcane of India

\begin{tabular}{|l|l|c|c|c|c|}
\hline Items & Particulars & $\begin{array}{c}\text { Sub Period I } \\
(\mathbf{1 9 7 0 - 7 1} \text { to } \\
\mathbf{1 9 8 4 - 8 5})\end{array}$ & $\begin{array}{c}\text { Sub Period } \\
\text { II (1985-86 } \\
\text { to 1999- } \\
\text { Area }\end{array}$ & $\begin{array}{c}\text { Sub Period } \\
\text { III (2000-01 } \\
\text { to 2014-2015) }\end{array}$ & $\begin{array}{c}\text { Study } \\
\text { Period } \\
(\mathbf{1 9 7 0 - 7 1} \text { to } \\
\mathbf{2 0 1 4 - 2 0 1 5 )}\end{array}$ \\
& Standard & 3.2348 & 1.7503 & 3.7607 & 5.0595 \\
& Error & 9.136 & 63.955 & 8.114 & 274.945 \\
& F. Value & 0.413 & 0.831 & 0.384 & 0.865 \\
& R & $1.9 * * *$ & $2.4 * * *$ & $1.5 * *$ & $1.6^{* * * *}$ \\
& Growth rate & & & & \\
\hline Production & Standard & 2.5932 & 1.3387 & 3.9565 & 4.2193 \\
& Error & 63.955 & 112.450 & 9.739 & 395.312 \\
& F. Value & 0.831 & 0.896 & 0.428 & 0.902 \\
& R & $3.4 * * *$ & $3.8 * * *$ & $2.1 *$ & $2.5 * * *$ \\
& Growth rate & & & & \\
\hline Productivity & Standard & 2.8706 & 1.4907 & 4.5996 & 6.2319 \\
& Error & 88.027 & 88.027 & 6.255 & 128.30 \\
& F. Value & 0.871 & 0.871 & 0.325 & 0.75 \\
& R & $1.5 * * *$ & $1.4 * * *$ & $0.6 * *$ & $0.9 * * *$ \\
& Growth rate & & & & \\
\hline
\end{tabular}

$* * *, * *, *$ indicates at $1 \%, 5 \%$ and $10 \%$ level of significance respectively

Note: Calculated by author from the data obtained from Department of Agricultural Cooperation \& Farmers Welfare, Government of India. 
Table.4 Growth Rate in Sugar Export and Import in India

\begin{tabular}{|c|c|c|c|c|c|}
\hline Items & Particulars & $\begin{array}{c}\text { Sub Period I } \\
\text { (1971 to } \\
1985)\end{array}$ & $\begin{array}{l}\text { Sub Period } \\
\text { II (1986 to } \\
2000)\end{array}$ & $\begin{array}{l}\text { Sub Period } \\
\text { III }(2001 \text { to } \\
2015)\end{array}$ & $\begin{array}{l}\text { Study Period } \\
\text { (1971 to } \\
\text { 2015) }\end{array}$ \\
\hline Export & $\begin{array}{l}\text { Standard Error } \\
\mathrm{F} \text {. Value } \\
\mathrm{R}^{2} \\
\text { Growth rate }\end{array}$ & $\begin{array}{c}0.049 \\
1.11 \\
0.079 \\
-5.30^{* * *}\end{array}$ & $\begin{array}{c}0.100 \\
3.27 \\
0.201 \\
16.76^{* * *}\end{array}$ & $\begin{array}{c}0.087 \\
0.79 \\
0.057 \\
-8.10^{* * *}\end{array}$ & $\begin{array}{c}0.020 \\
2.49 \\
0.050 \\
3.04^{* * *}\end{array}$ \\
\hline Import & $\begin{array}{l}\text { Standard Error } \\
\mathrm{F} \text {. Value } \\
\mathrm{R}^{2} \\
\text { Growth rate }\end{array}$ & $\begin{array}{c}0.341 \\
12.94 \\
0.499 \\
90.46^{* * *}\end{array}$ & $\begin{array}{c}0.204 \\
0.39 \\
0.030 \\
12.19^{* * *}\end{array}$ & $\begin{array}{c}0.137 \\
2.70 \\
0.172 \\
20.12^{* * *}\end{array}$ & $\begin{array}{c}0.039 \\
27.26 \\
0.380 \\
18.84^{* * *}\end{array}$ \\
\hline
\end{tabular}

*** indicates at $1 \%$ level of significance respectively

Source: http://stat.wto.org/StatisticalProgram/WSDBViewData.aspx?Language=E

Fig.1 Trend in area of sugarcane in Uttar Pradesh, Maharashtra and India (1970-71 to 2014-15)

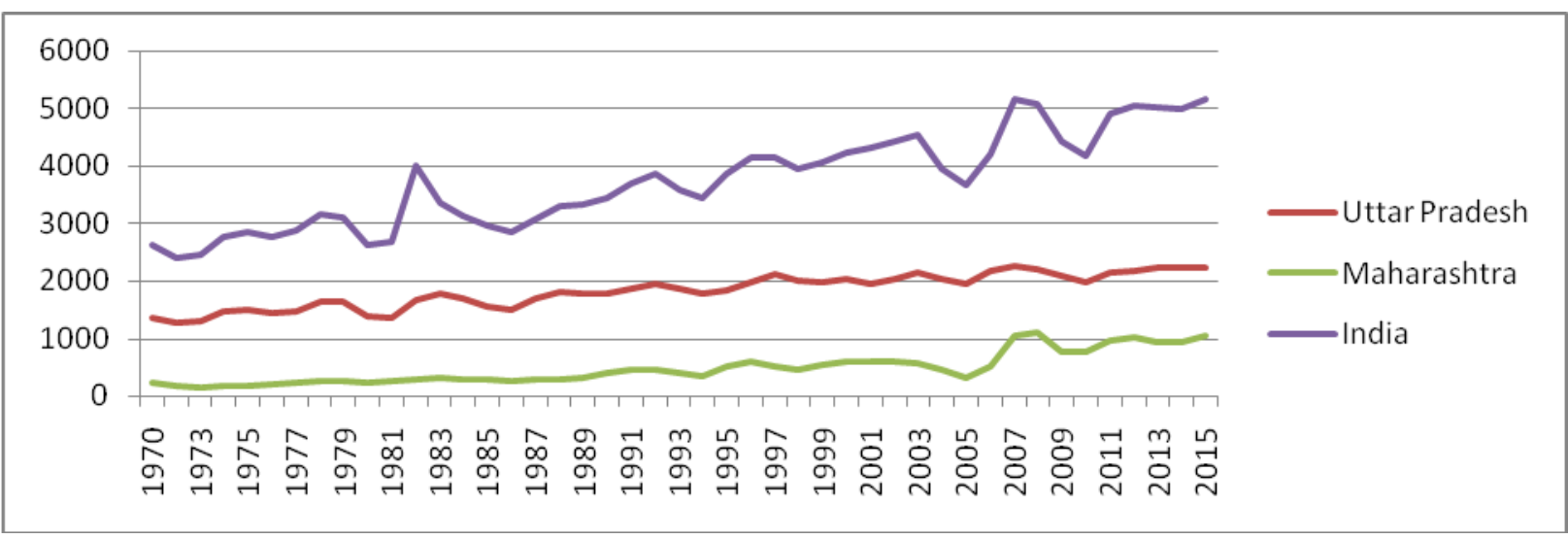

Fig.2 Trend in production of sugarcane in Uttar Pradesh, Maharashtra and India (1970-71 to 2014-15)

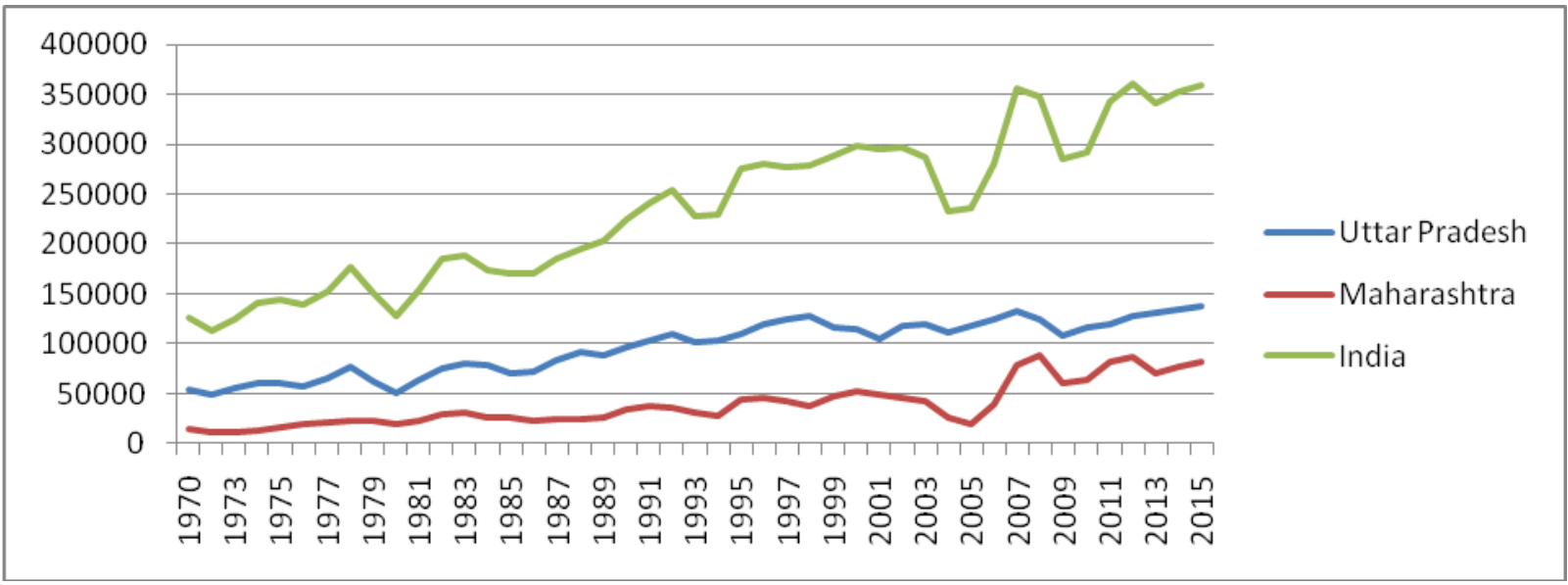


Fig.3 Trend in productivity of sugarcane in Uttar Pradesh, Maharashtra and India (1970-71 to 2014-15)

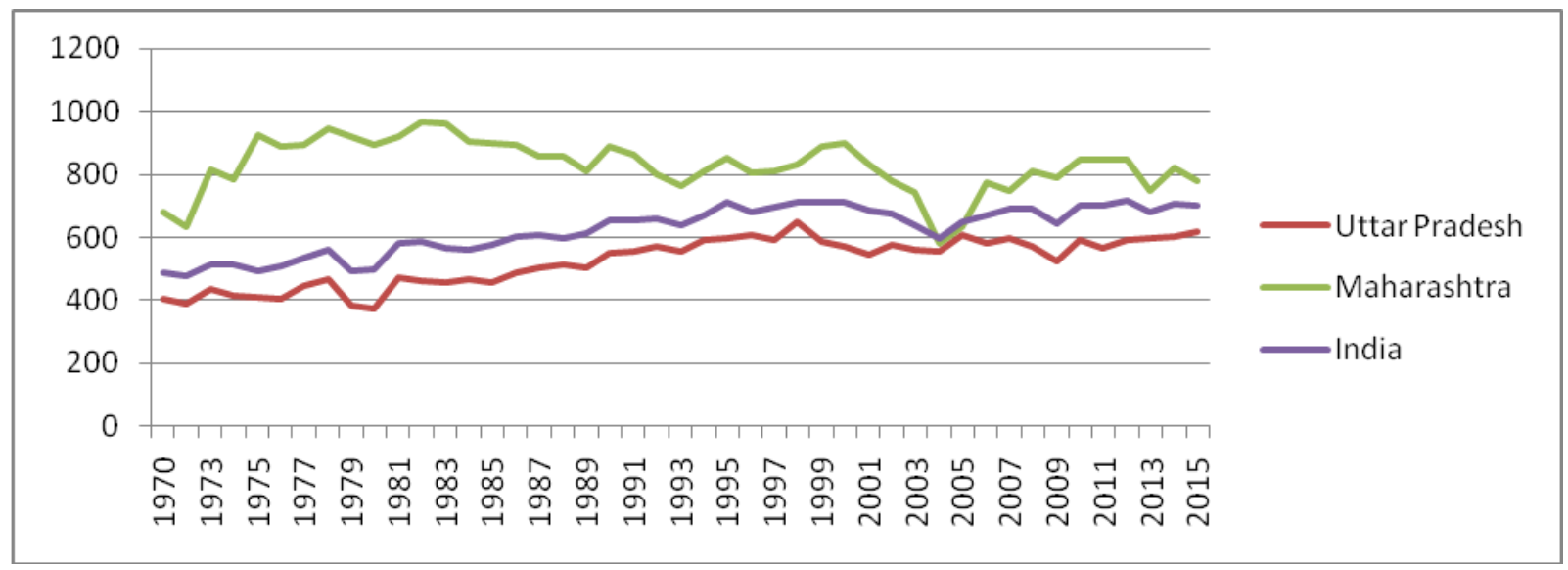

Fig.4 Trend in sugar import and export in India (1970-71to2014-15)

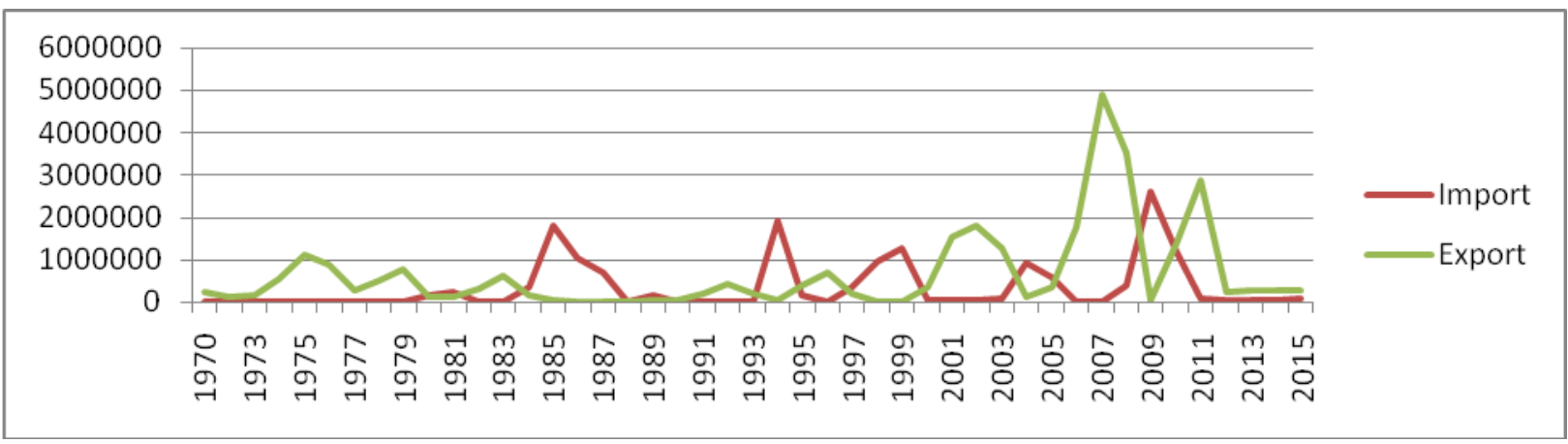

Table 4 indicate that the growth rate of sugar export and import in India from 1971 to 2015. Sub period II (1986 to 2000) showed positive and significant growth rate with 16.76 per cent while sub period I (1971 to 1985) and sub period III (2001 to 2015) showed negative and significant growth rate with 5.30 per cent and 8.10 per cent respectively in export of sugar. In overall study period (1971 to 2015), compound annual growth rate was positive and significant with 3.04 per cent. All the period showed positive and significant growth rate in import of sugar and highest growth rate was observed in sub period I (1971 to 1985) with 90.46 per cent due to less production of sugarcane and more demand of sugar in the country. Sub period II (1986 to 2000) and sub period III (2001 to 2015) showed growth rate of 12.19 per cent and 20.12 per cent respectively. During study period (1971 to 2015) import of sugar increased with 18.84 per cent per annum.

Sugarcane is growing as a major case crop all over the parts of India and it plays pivotal role in the national economy. Compound annual growth rate was used to analysis the growth rate in area, production and productivity of sugarcane in Uttar Pradesh, Maharashtra and overall India. Trade of sugar was also analyzed by using compound annual growth rate.

In Uttar Pradesh, all the sub period and overall period showed positive and significant growth rate in area, production and 
productivity of sugarcane. Sub period II got highest growth rate in area, production and productivity with 2 per cent, 4.3 per cent and 2.3 per cent respectively. In case of Maharashtra growth rate in area and production of sugarcane showed positive and significant growth rate in all period while sub period II and overall study period showed negative growth rate in productivity. Sub period III got highest growth rate in area and production of sugarcane with 6 per cent and 7 per cent respectively. Highest growth rate $(2.1 \%)$ in productivity of sugarcane was observed in sub period I. Positive and significant growth rate in area, production and productivity were observed for all the periods in overall India. In sub period II, growth rate in area and production were reported highest with 2.4 per cent and 3.8 per cent respectively. Highest growth rate $(1.5 \%)$ in production of sugarcane was observed in sub period I. Positive and significant growth rate (16.76\%) was observed in sub period II, while negative growth rate was observed in other sub periods in export of sugar. Positive significant growth rate was observed in import of sugar in all periods and highest growth rate was reported in sub period I (Fig. 1-4).

Policy interventions are required to encourage the production of sugarcane crop in India. Further, the crop productivity needs to be improved through high yielding varieties of seeds, improved cultivation technologies and better soil and water management. The area under sugarcane is increasing day by day but its productivity is almost stagnant. So, there is needed to make efforts for improvement in productivity.

\section{References}

Acharya, S.P., Basavaraja, H., Kunnal, L.B., Mahajanashetti, S.B. and Bhat, A.R.S. 2012. Growth in area, production and productivity of major crops in Karnataka. Karnataka J. Agric. Sci., 25 (4): 431-436.

Anonymous, Maharashtra State at a Glance, Directorate of Economics and Statistics, Maharashtra, 2015

Anonymous, Uttar Pradesh State at a Glance, Directorate of Economics and Statistics, Uttar Pradesh, 2015

Jagannathan, N. 1998. Trends and patterns of agricultural growth across crops in India. Monthly Public Opinion Surveys. 43(5): 7-11.

Kalamkar, S.S., Atkare, V.G, and Shende N.V. 2002. An Analysis of Growth Trends of Principal Crops in India. Agricultural Science Digest 22 (3): 153 $-156$.

Kale, V.C., Rajmane, K.D. and Waghmare, R.R. 1998. Trends in Agricultural growth in Parabhani district of Maharashtra State. J. Maharashtra Agric. Univ., 12(3): 361-363.

Kannan, E., 2012. Trends in India's agricultural growth and its determinants. Asian Journal of Agriculture and Development, 8, 79-98,

Krishna, S.R., Priya and Bajpai, P.K. 2011. Computation of Compound Growth Rates for Sugarcane Using Non-Linear Growth Models. Indian Journal of Sugarcane Technology, 26(2): 33-39.

Kumar P, Mittal S. 2006. Agricultural Productivity Trends in India: Sustainability Issues. Agricultural Economics Research Review 19, 71-88.

Rajarathinam, A. and Parmar, R.S. 2011. Application of parametric and nonparametric regression models for area, production and productivity trends of castor (Ricinus communis L.) crop. Asian Journal of Applied Sciences, 4(1): 42-52.

Samui, R.P., Kulkarni, P.S., and Vaidya, N.G. 2005. On growth and fluctuation of production, area and yield of sugarcane 
in the districts of Maharashtra. Agricultural Situation in India, 52, 4153.

Sihmar, R. 2014. Growth and instability in Agricultural Production in Haryana: A District level analysis, International Journal of Scientific and Research Publications, 4 (7), pp. 1-12.

Singh, D. and Swarup, R. 1988. Trend in production, productivity and acreage of pulses in Himachal Pradesh. Agric. Situ. India, 43(4): 283-285.

Srivastava, A.S. and Srivastava, R.S.L. 2003. Growth and instability in sugarcane production in Uttar Pradesh: a regional study. Indian Journal of Agricultural Economics. 58(2): 279-282.

Tyagi, R.C. and Hasnain, I., 2001. Growth Pattern of Sugarcane and Problems at its Marketing in India. The Bihar Journal of Agricultural Marketing, 9 (1): 51-63, Vanpal, K.B., Pant, D.C. Burak, S.S., Shekhawat R.S. and Mehra, J. 2015. Growth and Instability in Production of Cumin in Rajasthan, Journal Agric. Res. Technol. 40 (2), pp. 309-314.

\section{How to cite this article:}

Ajay Kumar and Rakesh Singh. 2018. Dynamics of Area, Production, Productivity and Trade of Sugarcane in India: Evidences from Uttar Pradesh and Maharashtra, India. Int.J.Curr.Microbiol.App.Sci. 7(05): 3484-3491. doi: https://doi.org/10.20546/ijcmas.2018.705.402 